\title{
研究課題別事後評価結果
}

1. 研究課題名「水を電子源とする人工光合成システムの構築」

2. 研究代表者名及び主たる研究参加者名 (研究機関名·職名は研究参加期間終了時点)

研究代表者

井上 晴夫 （首都大学東京都市環境学部 学部長）

主たる共同研究者

石谷 治 （東京工業大学大学院理学研究科 助教授）

3. 研究内容及び成果

本研究では地球環境に調和寸る「水を原料(電子源、酸素源)とする人工光合成型物質変換 およびエネルギー変換システム」の構築へのブレークスルーを得ることを目的としている。地球 上に於ける理想的な「物質変換およびエネルギー変換システム」である植物の営む光合成は水 分子から電子を二酸化炭素に移動させる反応である。人工的な光合成をフラスコの中で実現す ることは人類の夢であり世界中で研究されているが、その最大の問題は水分子から電子を取るこ とが困難な点にあった。そのような背景で、最近、研究代表者が独自の発想とアプローチで特別 の金属錯体に可視光を当てると水分子から電子を取ることができることを見出した。本研究はこの 発見を手がかりに人工光合成実現のための指針を得ようとするものである。本研究により得られ た指針により人工光合成型物質変換システム構築が可能になれば、水分子からの水素生成、二 酸化炭素の還元といら物質循環とエネルギーの両面でのクリーン・リサイクルシステムが達成でき ることになる。

これまでにルテニウムポルフィリン錯体による水を電子源、酸素源とする高効率、高選択的な光酸 素化反応を初めて見出している。二酸化炭素の光還元においても世界最高の量子収率を示す 反応系を見出した。

（1）水を電子源とする光増感酸素化反応の発見とその高効率化

電子受容体として $\mathrm{K}_{2} \mathrm{Pt}(\mathrm{IV}) \mathrm{Cl}_{6}$, 基質としてアルケン類の共存下、塩基性 $10 \%$ 含水アセトニトリル 溶液中、凍結脱気後、可視光 (420nm)をRuポルフィリンに照射すると効率よくアルケンが酸素化 され主生成物として対応寸るエポキシ化合物が生成した。エポキシ化合物中の酸素原子は水分子 に由来することを明らかにした。アルケン類の光エポキシ化については高い量子収率( $60 \%)$ で 高いエポキシ化選択性(>97\%)を実現した。

（2）水を電子源、酸素源とする不斉酸素化反応

ポルフィリン環にビナフチル不斉置換基を導入した新規不斉増感剂 Ruポルフィリンを合成し光 不斉酸素化反応について検討した。スチレン、ヘキセンが比較的高い不斉収率(e.e. >70\%) でエポキシ化されることを見出した。

（3）水を電子源、酸素源とするアルカン水酸化反応への展開 
アルカン類についても水を酸素源とする光ヒドロキシル化が進行することを見出した。アルカン のヒドロキシル化は人工 Methane mono-oxygenase モデルとしても注目される。特に、上記不斉 $\mathrm{Ru}$ ポルフィリンではヘキセンの光ヒドロキシル化でも若干の不斉誘導が観測された。オキソ体酸 素原子による水素引き抜き一 $\mathrm{OH}$ 移動 (rebound mechanism) で立体保持の酸素化の実例として大 変興味深い。

（4）水を電子源と寸る光増感酸素化反応の反応機構の解明と活性種の検討

$\mathrm{Ru}(\mathrm{II})$ ポルフィリンを増感剤とする光酸素化反応の反応機構の詳細を検討した。1)反応系の液

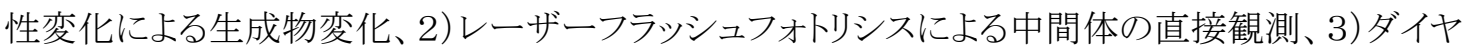
モンド電極による詳細な電気化学的検討、4) DFT 計算による活性種の電子構造と反応性の違い、 などの検討から $\mathrm{Ru}(\mathrm{II}) \mathrm{TMP}$ への光照射により電子受容体への一電子移動後、ポルフィリンカチオ ンラジカルを経由して明確に2種のポルフィリン活性種が存在することを明らかにした。レーザー フラッシュフォトリシスによる反応中間体の直接観察に成功した。それぞれ異なる時間スケールで $\mathrm{Ru}$ ポルフィリンの励起三重項、カチオンラジカル、活性中間体 I、活性中間体 II、合計 4 種類の反 応中間の観測に成功した。さらに詳細な速度解析から各過程の速度定数を決定することができた。 水分子が水酸化物イオンの形でポルフィリンカチオンラジカルの金属中心に配位し、プロトン脱 離を経て活性化されることを明らかにすることができた。ルテニウム触媒化学の視点からは、これ までは高原子価ルテニウム(4価、6価など)が注目されてきたが、本研究で見出した、三価ルテニ ウムによる触媒反応は極めて注目すべきものといえる。

（5）異方性を有寸る光反応の構築と光電子移動系への展開

二酸化チタン半導体の伝導帯への電子注入による水素発生系 (犠牲試薬を含まない電子受 容系)を構築することができた。しかし、還元末端 (水素発生)の反応効率がまだ極めて低い。層 状半導体ニオブ酸の層間に界面活性剤と共にポルフィリン錯体を取り込ませることに初めて成功 した。異方性を有する化学反応場として溶液中に分散させ可視光照射による水素発生にも成功 した。水素発生量子収率を5\%まで向上させることができた。

新規多フッ素化界面活性剤とカチオン交換性粘土が形成するハイブリッド化合物を異方性光 反応場として構築し光電子移動反応系への展開を図っている。層内に取り込まれた Ru ポルフィリ ンからニオブ酸伝導帯への電子注入によるカチオンラジカルの生成とその減衰挙動を直接レー ザーフラッシュフォトリシスにより観測することができた。伝導帯からポルフィリンへの逆電子移動は 極めて遅く、数10マイクロ秒と 100 マイクロ秒以上の少なくとも複数の過程が含まれることを見出し た。これらはポルフィリンの層状半導体への配向状態を反映しているものと解釈される。また、層 内に溶媒、基質が進入拡散し電子移動速度定数が一桁増大寸ることを見出した。巨視的にも異 方性を有するマイクロチャンネルプレートの光反応場への展開に着手した。

（6）二酸化炭素還元との共役

水を電子源とする光による二酸化炭素還元系の構築をめざし金属ポルフィリンと二酸化炭素還 元能を有するレニウム錯体の連結系分子を新たに合成しその光化学挙動について検討した。金 属ポルフィリンへの S2 励起により、ポルフィリンからレニウム錯体への電子移動に続いて二酸化炭 
素還元による一酸化炭素の生成に成功した。

$\left[\operatorname{Re}\left\{(\mathrm{MeO})_{2} \mathrm{bpy}\right\}(\mathrm{CO})_{3}\left\{\mathrm{P}(\mathrm{OEt})_{3}\right\}^{3}\right]^{+}$光増感剤、 $\left.[\mathrm{Re}(\mathrm{bpy})](\mathrm{CO})_{3}(\mathrm{MeCN})\right]^{+}$を触媒として含む複合系 を用いると、 $\mathrm{CO}_{2}$ が還元され $\mathrm{CO}$ が生成する量子収率が 0.47 と、これまでで世界最高の効率を示 すことを見出した。

\section{(7) 光捕集系の構築}

光捕集系構築の着手として、思い通りに分子を吸着させ、思い通りにその配向を制御すること に挑戦している。層状化合物表面に対して、会合せずイオン交換容量が100\%まで単分子吸着 させる方法を見出した。吸着分子と層状化合物表面の双方の電荷間距離の整合が吸着挙動を 支配する重要な因子であることを明らかにした。（size matching rule）吸着している分子の中で特 定の分子配向だけを変化させることにも成功した。

\section{4. 事後評価結果}

4-1. 外部発表(論文、口頭発表等)、特許、研究を通じての新たな知見の取得等の研究成果の状況

発表論文数は国内8編、海外124編、小計132編、口頭発表数は国内192件、海外69件、小計 261 件、特許出願件数は国内 3 件、海外 1 件と充分な件数である。研究が基礎的フェーズであり、工 業所有権の取得が少ないのはやむを得ない。

本研究は「水を電子源とする人工光合成システムの構築」と題し、地球環境に調和する水を原料 (電子源、酸素源)とする人工光合成型物質変換及びエネルギー変換システムの構築を目指した研 究である。

地球上に於ける理想的な物質変換およびエネルギー変換システムは、植物の営む光合成反応 であろう。この反応は水分子から電子を二酸化炭素に移動させる反応である。人工的な光合成反 応をフラスコの中で実現することは、人類の夢であり、世界中で研究されてきたが、実現は未だ疑 問視されてきた。その最大の問題は、水分子から電子を取ることが困難な点にあった。そのような 背景の中で、この研究チームの研究代表者らが、最近、独自の発想とアプローチで、特別の金属 錯体に可視光を当てると、水分子から電子を取ることができることを見出した。この研究は、この発 見を手がかりに人工光合成実現のためのブレークスルーの指針を得ようとするものである。

この研究の中心課題である、Ruポルフィリン類を増感剤、水を電子源、酸素源とする光化学的酸 素化反応の典型例は、電子受容体としてK2Pt(IV)Cl6、基質としてアルケン類の共存の下で、塩 基性10\%含水アセトニトリル溶液中で涷結脱気後、可視光(420nm)をRuTMP(CO)に照射すると効率 よくアルケンが酸素化され、主生成物として、対応するエポキシ化合物が生成された。D2Oを用い た実験からエポキシ化合物中の酸素原子は水分子に由来することが明らかとなった。反応条件を 徹底的に検索した結果、アルケン類の光エポキシ化については高い量子収率( 60\%)で高いエポ キシ化選択性(>90\%)を実現できた。

更にポルフィリン環にビナフチル不斎置換基を導入した新規不斉増感剤Ruポルフィリンを合成 し、光不斉酸素化反応について検討すると、スチレン、へキセンが比較的高い不斉収率(>70\%)で エポキシ化されることを見出した。つまり水を電子源、酸素源として不斎酸素化反応が起こったこと 
を示す。

同様に、アルカン類についても水を酸素源とする光ヒドロキシル化が進行していることを見出した。 強い酸化剤が無くても室温下で、光と水によるアルカンのヒドロキシル化が起こっており、注目され る。特に上記の不斉ポルフィリンでは、へキセンの光ヒドロキシル化でも若干の不斉誘導が観測さ れた。オキソ体酸素原子による水素引き抜き、一 $\mathrm{OH}$ 移動で立体保持の酸素化の事例として注目 される。さらに人工光合成の重要な単位反応として期待されるRu(II)ポルフィリンを増感剤とする光 酸化反応の反応機構を検討し、 Ru ( II ) TMPへの光照射により電子受容体への1電子移動後、ポ ルフィリンカチオンラジカルを経由して明確に2種のポルフィリン活性種が存在することを確認した。 更に詳細な速度解析から各過程の速度常数を決定することができ、水分子が水酸化物イオンの形 でポルフィリンカチオンラジカルの金属中心に配位し、プロトン脱離を経て活性化されることを明ら かにした。これまでルテニウム触媒化学の視点からは、4価、6価などの高原子価ルテニウムが注 目されてきたが、本研究で見出した3価のルテニウムによる触媒反応は極めて注目される。

総括して実用化にはまだ遠いものの、継続的な研究を期待している。

\section{4-2. 成果の戦略目標・科学技術への貢献}

特別の金属錯体に可視光を当てると水分子から電子を取ることが可能になったが、このことは人 工光合成への第1歩である。この反応は緑色植物の光合成のように、光エネルギーと水を利用して 二酸化炭素を還元し、資源化できる人工的なシステム(人工光合成)が可能になれば地球温暖化 抑制の根本的な解決法に結びつく可能性がある。多様な配位子と中心金属の組み合わせにより、 太陽光を効率よく吸収できる金属錯体を発見できればこの夢は実現に結びつく。井上チームの中 では、特に優れた二酸化炭素の還元触媒・電気化学的触媒機能を有するレニウムビピリジン錯体 に注目して開発を進めており、成果が期待される。この錯体の特長は、(1)高い二酸化炭素還元選 択性を有し、水が共存する系でも水素の発生は僅かで二酸化炭素還元が優先的に起こること、ま た(2)在来の光触媒のように、多電子還元を行う助触媒を共存させる必要がなく、単独で二酸化炭 素の 2 電子還元を実現できる点にある。これまでの研究では反応条件を最適化すると一酸化炭素 生成の量子収率が 0.38 とこれまで報告された均一系二酸化炭素光還元触媒の中で最も効率の良 いデータが得られており、成果が期待される。それにしても自然界の仕組みが複雑、絶妙にして、 かつエネルギーミニマム型であることに改めて感嘆の念を禁じ得ない。このような研究は例が少なく、 高い評価をされたアドバイザが多かった。総じて人工光合成の実現が視野に入る程度まで研究が 進展したと評価できる。ただ各サブグループの成果が互いにフィードバックされグループ全体の研 究レベルが上がったといら印象は薄い。

今後は光の吸収と二酸化炭素還元反応とを効率的に結びつける研究の進展が期待される。

\section{4-3. その他の特記事項 (受賞歴など)}

(1) 日本粘土学会賞 高木克彦:「粘土層間光化学を利用した光機能材料の研究」(2002年9 月） 
(2) The APA Prize for Young Scientist, Shunsuke Takagi: “The Nano-Structure Control of Complexes Composed of Porphyrin and Layered Materials, and their Applications to Photochemical Reactions.” (2005)

(3) 第48回粘土科学討論会最優秀講演賞 井上晴夫:「粘土表面における1価カチオン性色素 の吸着平衡」(2004)

(4) 54 回錯体化学討論会ポスター賞 上村直弥:「エネルギー移動と光電子移動機能を合せ持 つ直鎖状多核レニウム(1)ビピリジン錯体」(2004)

(5) 日本化学会第85春季年会学生講演賞 江口美陽、層状化合物表面におけるポルフィリン分 子の配向制御とその吸着挙動 (2005)

(6) Student Poster Prize at XXII International Conference on Photochemistry, Miharu Eguchi: “The Orientational Control of Porphyrin Molecule Adsorbed on Inorganic Nano-Sheet." (2005)

(7) 日本化学会第85春季年会「学生講演賞」(2005)「超分子錯体光触媒(1):Ru(II)-Re(I)連結錯体 を用いた可視光による高効率 $\mathrm{CO}_{2}$ 還元」佐藤 俊介 